\title{
21. GREENSCHIST FACIES HYDROTHERMAL ALTERATION OF OCEANIC GABBROS: A CASE STUDY OF ELEMENT MOBILITY AND REACTION PATHS ${ }^{1}$
}

\author{
John M. Fletcher, ${ }^{2}$ Christopher J. Stephens, ${ }^{3}$ Erich U. Petersen, ${ }^{4}$ and Lisa Skerl ${ }^{2}$
}

\begin{abstract}
Oceanic gabbro from Leg 153 records retrograde metamorphism caused by progressive unroofing in the footwall of a brittle-ductile normal fault. Decreasing temperature is reflected by amphiboles that evolved from pargasitic to actinolitic compositions. Highest degrees of water-rock interaction are associated with greenschist facies hydrothermal alteration that produced actinolite + chlorite \pm talc \pm epidote \pm prehnite \pm pyrite \pm quart $z \pm$ titanite. Alteration is strongest near microfractures and veins that we interpret to be the main fluid conduits.

Chlorite and actinolite make up 50\% of highly altered samples. Chlorite typically occurs as zoned coronas around felted cores of actinolite, and reaction textures show that chlorite predominately replaces plagioclase and actinolite replaces olivine. Reaction textures and strong linear correlations in the enrichment of secondary chlorite and actinolite and depletion of primary plagioclase and olivine indicate that the two reactions operated simultaneously. Based on mass-balance calculations and lack of significant variations in whole-rock composition, we infer that calcium required to transform olivine to actinolite was derived from the alteration of plagioclase to chlorite; whereas iron and magnesium required to transform plagioclase to chlorite were derived from the amphibolitization of olivine.

Mass balance of hydrothermal alteration of troctolitic gabbro from Hole $922 \mathrm{~A}$ shows that the dominant metasomatic change was the addition of water, approximately $5110 \mathrm{~mol} / \mathrm{m}^{3}$. The enrichment patterns of other elements are largely antithetic to patterns observed in submarine hydrothermal water relative to seawater. Therefore, alteration could have occurred in the root zone of such hydrothermal systems.
\end{abstract}

\section{INTRODUCTION}

Oceanic gabbros recovered in Leg 153 are exposed in the footwall of an east-dipping, brittle-ductile, normal fault, which makes up the western wall of the median valley of the Mid-Atlantic Ridge, immediately south of the Kane Fracture zone (MARK area) (Karson, 1990). Based on the metamorphic evolution documented in this study and the microstructural evolution documented by Fletcher, Ceuleneer, et al. (this volume), we can demonstrate that the gabbroic rocks in the MARK area record progressive tectonic denudation similar to that observed in Cordilleran metamorphic core complexes.

The most extensive hydrothermal alteration of these rocks produced the greenschist facies assemblage of actinolite + chlorite \pm talc \pm epidote \pm pyrite \pm quart \pm \pm titanite. The main goals of this study are to characterize mass transfer of this extensive alteration and to investigate the effects of fluid circulation on oceanic rocks that have occupied a wide range of crustal levels at a slow-spreading ridge. The occurrence of these rocks in a major fault zone suggests that pressure gradients created by the opening of fractures and veins may have been an important driving force of fluid flow. Therefore, we compare water:rock interactions in this setting with other well-documented, thermally driven systems.

'Karson, J.A., Cannat, M., Miller, D.J., and Elthon, D. (Eds.), 1997. Proc. ODP, Sci. Results, 153: College Station, TX (Ocean Drilling Program).

2Departamento de Geología, Centro de Investigación Científica y Educación Superior de Ensenada, P.O. Box 434843, San Diego, CA 92143-4843, U.S.A jfletche@cicese.mx

'Department of Earth Sciences, The University of Queensland, Brisbane, 4072. Australia. (Present address: School of Geology, Queensland University of Technology, 2 George Street, Brisbane, 4000, Australia.)

${ }^{4}$ Department of Geology and Geophysics, University of Utah, Salt Lake City, UT 84112-1183, U.S.A.

\section{METHODS}

Samples were collected mostly from Core $153-922 \mathrm{~A}-2 \mathrm{R}$, which had particularly high recovery. It also contains a suite of troctolitic gabbros that show a wide range of degrees of alteration $(0 \%-60 \%)$, but only small variations in protolith rock type. This study uses three main approaches to characterize mass transfer of hydrothermal alteration in the troctolitic gabbro. First, compositions and zoning patterns of phases were determined so that representative phase compositions could be used in system reactions. Special attention was given to phase compositions near disequilibrium reaction boundaries to characterize diffusive mass transfer in solid phases. Second, modal mineralogy was determined for the suite of variably altered troctolitic gabbros to define reaction paths or relative changes in abundance of primary and secondary phases. Third, whole-rock compositions were determined for the suite of variably altered troctolitic gabbros to identify chemical variations resulting from metasomatism. Based on reaction textures, a set of system reactions was generated using representative phase compositions. The system reactions were combined to produce a single reaction that fits changes in relative proportions of primary and secondary phases, as well as changes in whole-rock compositions.

Modal mineralogy was determined from microprobe-generated point counts. This routine was largely developed during this study and a detailed description of it follows. Peak intensities (counts/s) from wavelength dispersive spectrometry were collected for eight elements (K, Na, $\mathrm{Ca}, \mathrm{Mg}, \mathrm{Fe}, \mathrm{Si}, \mathrm{Al}$, and $\mathrm{Ti}$ ) over a rectangular grid of points. Each grid was defined to sample the largest possible surface area in each sample. The number of points varied from 700 to 2000 , and spacing between points was generally between 100 and $200 \mu \mathrm{m}$. To minimize analysis time, groups of four elements were measured in two different passes through the grid. This eliminated the time re- 
quired to change spectrometer positions at each grid point. Counting times were $1 \mathrm{~s}$ for all elements. A spot size of $1 \mu \mathrm{m}$ and a beam current of $30 \mathrm{nA}$ were used. The raw data were systematically sorted and classified into phases using Microsoft Excel 4.0 by the following procedural steps:

1. Totals for all eight intensities were calculated to sort out anomalously low analyses that were taken on epoxy or glass.

2. Intensities were divided by molecular weight, and analyses were normalized to total 100 . This converted the analyses to relative molar proportions that closely approximated cation ratios expected for different phases.

3. Analyses were classified into phases by sorting the following molecular ratios-once classified, the analyses were sequentially separated from the remaining unclassified analyses.

a. The ratio $(\mathrm{Fe}+\mathrm{Ti}) /(\mathrm{Si}+\mathrm{Mg}+\mathrm{K}+\mathrm{Na}+\mathrm{Ca}+\mathrm{Al})$ was used to separate opaque minerals from silicates.

b. The ratio $\mathrm{Na} /(\mathrm{Fe}+\mathrm{Mg})$ was used to separate plagioclase from amphibole, pyroxene, and olivine. Good plagioclase analyses have values greater than the threshold of about 12 .

c. The ratio $\mathrm{Ca} /(\mathrm{Fe}+\mathrm{Mg})$ separated calcic plagioclase from ferromagnesian minerals.

d. The ratio $(\mathrm{Mg}+\mathrm{Fe}) /(\mathrm{Al}+\mathrm{Ca})$ was used to separate olivine, orthopyroxene, and talc from clinopyroxene, amphibole, and chlorite analyses. The threshold value was about 10 . Among analyses with values greater than threshold values of 10 , the ratio $(\mathrm{Mg}+\mathrm{Fe}) / \mathrm{Si}$ was used to separate olivine $(=2)$ from orthopyroxene $(=1)$, from talc $(=0.75)$. Among analyses with values less than threshold values of 10 , the ratio $\mathrm{Ca} /(\mathrm{Mg}+\mathrm{Si}+\mathrm{Al})$ was used to separate pyroxene (= $1 / 3$ ) from amphibole $(=1 / 9)$, from chlorite $(=0)$.

Analyses with molecular ratios similar to the threshold values were labeled unclassifiable and separated from the data set. These analyses are likely to be hybrid analyses taken at grain boundaries. It is very unlikely that any hybrid analyses were generated by errors in analyzing the same points in the two different passes through the grid. The automatic stage-positioning system on the microprobe at the University of Utah has been tested by an internal routine and is accurate to within $1 \mu \mathrm{m}$ (R. Lambert, pers. comm., 1995). Additionally, it is unlikely that the population of hybrid analyses are systematically biased toward primary or secondary phases. Although individual grains of secondary phases are smaller and have larger relative proportion of grain boundaries for a given area, they generally occur in monomineralic clusters and pseudomorphically replace primary phases. Approximately $2 \%-5 \%$ of the analyses were labeled unclassifiable, which should not drastically affect the geochemical modeling in this study. Future work will include classifying these points using a neural network routine.

\section{METAMORPHIC OVERVIEW}

Amphiboles from gabbroic rocks of Leg 153 show a nearly continuous range in composition from high-Al pargasitic to low-Al actinolitic compositions (Fig. 1A). Similar compositional variations of amphiboles are observed in gabbroic rocks at other slow-spreading ridge locations (Mével, 1987, 1988; Mével and Cannat, 1991). Changes in composition of amphiboles in the gabbroic rocks from the MARK area correspond to systematic variations in the style of coeval deformation and degree of disequilibrium between amphibole and preexisting phases in the rock. The style of coeval deformation was determined through simple crosscutting relationships between minerals and microfabrics. The degree of disequilibrium was determined by smoothness of grain contacts and the presence of compositional zoning, which requires disequilibrium according to Gibbs' phase rule (e.g., Spear, 1993).
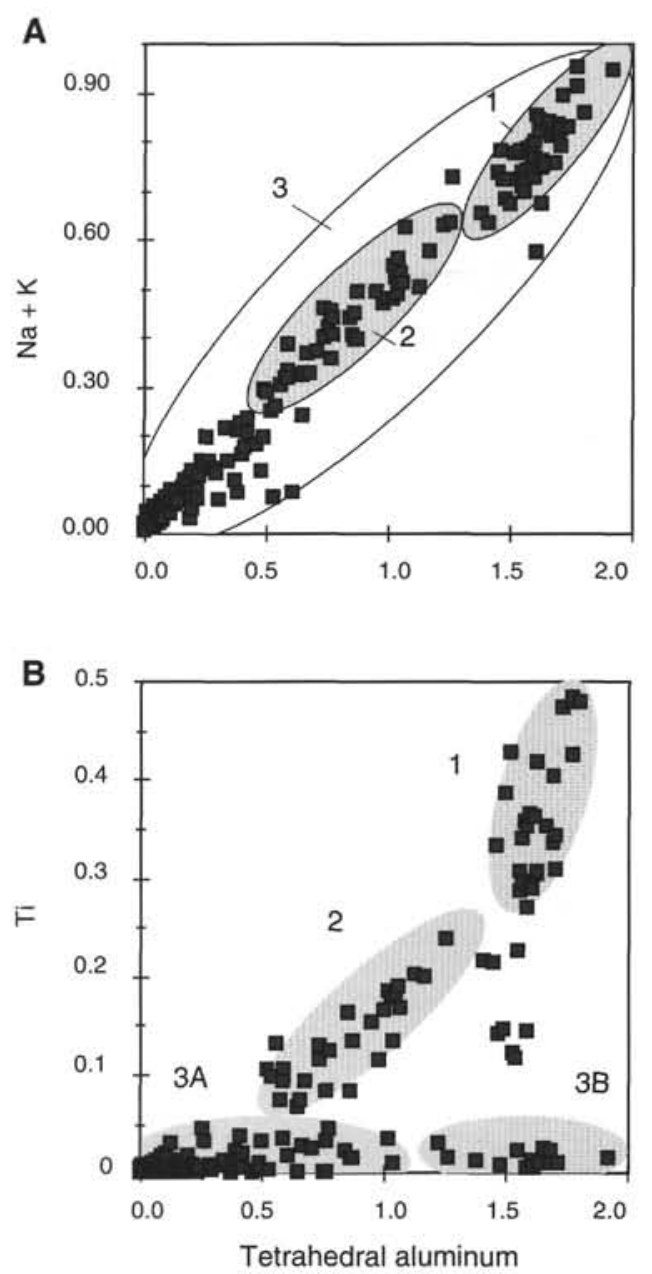

Figure 1. Compositional variations of amphibole from gabbroic rocks of Leg $153 ; n=230$. A. Tetrahedral aluminum is plotted vs. sodium + potassium. B. Tetrahedral aluminum is plotted vs. titanium.

Important populations of amphibole from gabbroic rocks of Leg 153 are defined by textural criteria and compositional variations in tetrahedral aluminum, alkalis, and titanium. For descriptive purposes, these populations are referred to by compositional fields shown in Figure 1. Amphiboles from Field 1 are brown and rich in aluminum, alkalis, and titanium (Fig. 1). They are found as individual grains and overgrowths on olivine and pyroxene. Contacts between brown amphibole and preexisting grains like plagioclase, pyroxene, and olivine are smooth, curviplanar, and show no textural evidence for disequilibrium. In dynamically recrystallized samples, amphiboles in Field 1 are commonly also neoblastic, suggesting that they crystallized before or during ductile deformation. In relatively undeformed samples, brown amphibole is associated with patches of anhedral plagioclase that have similar An compositions to euhedral cumulate plagioclase in the samples. We interpret amphibole from Field 1 to have crystallized late from a gabbroic magma that was largely in equilibrium with other primary igneous phases like plagioclase + clinopyroxene \pm orthopyroxene \pm olivine.

Amphiboles in Field 2 are green-brown and have intermediate aluminum, alkali, and titanium compositions (Fig. 1). Green amphiboles in Field 2 occur as overgrowths on preexisting pyroxene, olivine, and brown amphibole, but they are also found as the outer rim of zoned green-brown amphiboles or along cleavage planes, fractures, and inclusion trails in pyroxene. Green-brown amphiboles of Field 2 are commonly associated with $\mathrm{An}_{35}-\mathrm{An}_{45}$ plagioclase, which occurs as neoblast mosaics and zones of alteration along the margins and fractures in preexisting plagioclase grains with higher anorthite contents. Green amphibole is not commonly neoblastic, but it is associ- 
ated with recrystallization-dominated, semibrittle microfabrics, as discussed by Fletcher, Ceuleneer, et al. (this volume). We interpret green-brown amphibole in Field 2 and associated andesine to have formed from highly evolved, silicate melts, and/or from high-temperature, aqueous brines that were moderately out of equilibrium with other preexisting phases, like clinopyroxene, olivine, and labradorite plagioclase.

Amphiboles from Field $3 \mathrm{~A}$ and $3 \mathrm{~B}$ are low in alkalis and titanium, but show extreme variability in tetrahedral aluminum content (Fig. 1). Amphiboles in Field $3 \mathrm{~A}$ are colorless, and occur as fibrous mats pseudomorphically replacing olivine, feldspar, and pyroxene. They are commonly associated with chlorite \pm talc \pm epidote \pm prehnite \pm pyrite \pm quartz \pm titanite, suggesting that alteration occurred at greenschist facies or lower conditions (Spear, 1993). The degree of disequilibrium between minerals of the greenschist facies parageneses and primary igneous phases is extreme, as shown by highly irregular to sutured grain boundaries and by compositional zoning in both the primary and secondary phases near grain boundaries. This alteration is commonly localized along fractures and veins, and can result in the complete replacement of olivine in highly fractured samples.

Amphiboles in Field $3 \mathrm{~B}$ have similar grain shape and size as the brown amphibole of Field 1, but they are nearly colorless and have much lower titanium contents (Fig. 1). Samples containing amphiboles from Field 3B always show extensive hydrothermal alteration and contain a significant population of amphiboles from Field 3A. Therefore, we interpret the amphiboles in Field 3B to represent primary amphiboles, which were modified in composition but not destroyed during later periods of strong hydrothermal alteration that also produced new amphiboles of Field $3 \mathrm{~A}$.

In summary, crosscutting relationships and reaction textures described above show that amphibole compositions evolved from Field 1 to Field 3 through time. The compositional trends of decreasing $\mathrm{Al}$, $\mathrm{Ti}$, $(\mathrm{Na}+\mathrm{K})$, and increasing $\mathrm{Si}$ in amphiboles from Field 1 to 3 suggest that temperature and pressure decreased through time (e.g., Spear, 1993). The hornblende-plagioclase exchange thermometer (Spear, 1980) was not used in this study because plagioclase was not always in equilibrium with amphibole, especially Field 3 amphiboles. However, our proposed retrograde path is confirmed by change in the coeval deformational fabrics from ductile microstructures associated with Field 1 amphiboles, to brittle and ductile microstructures associated with Field 2 amphiboles, to purely brittle microstructures associated with Field 3 amphiboles (see also Fletcher, Ceuleneer, et al., this volume). This pressure-temperature path and evolution of microstructures is similar to those observed in Cordilleran metamorphic core complexes (e.g., Bartley et al., 1990; Fletcher et al., 1995). This is consistent with the idea that the gabbroic rocks in the MARK area also record progressive unroofing in the footwall of a brittle-ductile normal fault.

Amphiboles from Fields $3 \mathrm{~A}$ and $3 \mathrm{~B}$ are associated with the most extensive hydrothermal alteration recorded by gabbroic rocks from Leg 153. In contrast to amphiboles from Fields 1 and 2, which generally make up $0 \%-4 \%$ of the rock, chlorite and actinolitic amphibole from Field $3 \mathrm{~A}$ make up as much as $50 \%$ of highly altered samples. The main goal of this study is to characterize element mobility associated with high degrees of this greenschist facies hydrothermal alteration.

\section{PHASE COMPOSITIONS AND REACTION TEXTURES}

Samples of troctolitic gabbro from Hole 922A were chosen for characterization of mass transfer because they display a wide range of degrees of alteration $(0 \%-60 \%)$ with very little variation in protolith composition. Olivine and plagioclase typically make up $90 \%-$ $95 \%$ of the primary minerals, and clinopyroxene, orthopyroxene, and brown amphibole make up the remaining 5\%-10\%. Relict plagioclase in the sample suite varies in composition from $\mathrm{An}_{78}$ to $\mathrm{An}_{71}$, which is about the same or less than the variation seen in individual samples (Table 1). Magnesium numbers $(\mathrm{Mg} /[\mathrm{Mg}+\mathrm{Fe}+\mathrm{Mn}])$ of olivine also show little variation $(0.86-0.81)$ but olivine compositions could not be determined in the most highly altered samples where it had been completely consumed (Table 1). Clinopyroxene and brown amphibole are not present in all samples, but do occur in both weakly and highly altered samples. Magnesium numbers for clinopyroxene ranged from 0.89 to 0.85 (Table 1 ). Brown amphibole typically has edenitic- to pargasitic-hornblende compositions (Table 1). Low variation in primary-phase compositions allow greater consistency in modeling reaction paths and mass transfer of hydrothermal alteration.

Felted mats of actinolite \pm talc \pm chlorite surrounded by coronas of chlorite form the dominant reaction texture that characterizes lowgrade alteration in the troctolitic gabbro (Fig. 2). Inner contacts of chloritic halos with actinolitic mats are generally sharp despite the numerous, irregularly shaped grains that define them. However, outer contacts between chloritic halos and primary plagioclase are finely sutured, suggesting that chlorite was replacing feldspar (Fig. 2). Alteration is strongest near chlorite-filled veins. The types of vein-filling minerals are strongly controlled by the host grain that the vein cuts. Olivine-hosted veins contain actinolite and talc, whereas feldspar-hosted veins contain chlorite. In weakly altered samples, veins typically change from well-defined microstructures with discrete walls in feldspar grains to thicker diffuse zones of alteration in olivine grains. In highly altered samples, chlorite-filled veins typically cut feldspar and chloritic coronas but never the felted mats of actinolite. Examples of partially developed actinolitic mats show that the chlorite-actinolite contact follows the primary-grain contact between olivine and plagioclase (Fig. 3). More importantly, the thickness of the chloritic halo is directly proportional to the thickness of the adjacent actinolitic mat. These textures demonstrate that (1) actinolite preferentially replaced olivine, and (2) chlorite preferentially replaced plagioclase. The sympathetic variations in thickness of chloritic halos and actinolitic mats suggest that the two reactions could have operated simultaneously and supplied necessary reactants to each site across the inner halo boundary. It is possible that calcium required to transform olivine to actinolite was derived from the alteration of plagioclase to chlorite, whereas iron and magnesium required to transform plagioclase to chlorite could have been derived from the replacement of olivine by amphibole.

The main difference between the spectrum of amphibole compositions from troctolitic gabbro of Hole $922 \mathrm{~A}$ and that of all gabbroic rocks from Leg 153 is that green-brown amphiboles from Field 2 are not present (compare Figs. 1 and 4). The subset of amphiboles from troctolitic gabbro also shows that Field $3 \mathrm{~A}$ of Figure 1 can be divided into two distinct populations. Amphiboles from Field $3 \mathrm{Ax}$ are much more abundant and are only found as matted cores of the coronitic replacement of olivine described above. Amphiboles in Field 3Ay are only found in the most highly altered samples, which do not contain olivine, and are seen directly replacing plagioclase. Besides containing more aluminum and alkalis, amphiboles in Field 3Ay have much lower $\mathrm{Mg} /(\mathrm{Mg}+\mathrm{Fe}+\mathrm{Mn})$ ratios than those from Field 3Ax (Figs. 4A, 4C). Plagioclase grains that are partially replaced by Field $3 a x$ amphibole typically have albite to oligoclase compositions. Therefore, textural evidence suggests that after olivine was completely consumed, amphibole with compositions that plot in Field 3 Ay continued to form at the expense of plagioclase. This reaction does not appear to have operated with any other net-transfer reaction, but could have operated with exchange reactions that modified compositions of existing phases.

Amphiboles in Field 3B are altered primary amphiboles, as previously described. They are depleted in titanium, have lower $\mathrm{Mg} /(\mathrm{Mg}$ $+\mathrm{Fe}+\mathrm{Mn}$ ) ratios (Fig. 4C), and generally occur in the more highly altered samples. It is possible that $\mathrm{Mg}$ from the depletion primary amphiboles was used in the amphibolitic replacement of plagioclase, which created amphiboles that plot in Field $3 \mathrm{Ay}$.

Coronitic chlorite displays strong and nearly continuous compositional zoning (Fig. 5). Along the outer contact with plagioclase, chlorite is higher in aluminum and has lower $\mathrm{Mg} /(\mathrm{Mg}+\mathrm{Fe}+\mathrm{Mn})$ ratios than chlorite along the inner contact with the actinolitic cores. 
Table 1. Representative phase compositions for suite of variably altered troctolite.

\begin{tabular}{|c|c|c|c|c|c|c|c|c|c|c|c|c|c|c|c|c|c|c|c|}
\hline \multirow{2}{*}{$\begin{array}{l}\text { Core, section, } \\
\text { interval }(\mathrm{cm})\end{array}$} & \multirow[b]{2}{*}{ Phase } & \multicolumn{18}{|c|}{ Representative analyses of primary phases } \\
\hline & & $\mathrm{Na}$ & $\mathrm{Ca}$ & $\mathrm{Mg}$ & $\mathrm{Fe}$ & $\mathrm{Si}$ & Al & $\mathrm{Ti}$ & $\mathrm{K}$ & $\mathrm{F}$ & $\mathrm{Cl}$ & Mn & $\mathrm{O}$ & Total & An & $\mathrm{Mg \#}$ & Tet Al & $\mathrm{Ti}$ & $\mathrm{Na}+\mathrm{K}$ \\
\hline \multicolumn{20}{|l|}{ 153-922A- } \\
\hline IR-1, 45-52 & Clinopyroxene & 0.28 & 15.95 & 10.10 & 3.04 & 24.07 & 1.46 & 0.64 & 0.00 & 0.03 & 0.02 & 0.05 & 43.23 & 98.88 & & 0.88 & & & \\
\hline $2 \mathrm{R}-1,5-11$ & Clinopyroxene & 0.36 & 16.13 & 9.96 & 2.92 & 24.49 & 1.65 & 0.66 & 0.01 & 0.00 & 0.01 & 0.10 & 43.87 & 100.14 & & 0.88 & & & \\
\hline $2 \mathrm{R}-1,65-71$ & Clinopyroxene & 0.20 & 15.94 & 10.43 & 3.05 & 24.92 & 1.21 & 0.36 & 0.01 & 0.00 & 0.02 & 0.10 & 43.99 & 100.23 & & 0.88 & & & \\
\hline $2 \mathrm{R}-3,25-31$ & Clinopyroxene & 0.35 & 15.66 & 10.01 & 2.83 & 24.40 & 1.64 & 0.72 & 0.02 & 0.02 & 0.00 & 0.10 & 43.62 & 99.38 & & 0.89 & & & \\
\hline $2 \mathrm{R}-3,71-77$ & Clinopyroxene & 0.31 & 15.99 & 10.07 & 2.94 & 24.27 & 1.67 & 0.76 & 0.00 & 0.19 & 0.01 & 0.12 & 43.65 & 99.99 & & 0.88 & & & \\
\hline $2 \mathrm{R}-4,20-26$ & Clinopyroxene & 0.35 & 14.82 & 10.27 & 3.79 & 24.33 & 1.60 & 0.63 & 0.00 & 0.01 & 0.00 & 0.11 & 43.48 & 99.39 & & 0.86 & & & \\
\hline $2 \mathrm{R}-4,100-106$ & Clinopyroxene & 0.35 & 15.68 & 9.89 & 3.52 & 24.17 & 1.61 & 0.63 & 0.00 & 0.00 & 0.01 & 0.13 & 43.33 & 99.32 & & 0.86 & & & \\
\hline $2 \mathrm{R}-1,41-48$ & Olivine & 0.01 & 0.01 & 27.56 & 11.09 & 18.81 & 0.00 & 0.00 & 0.00 & 0.00 & 0.00 & 0.13 & 42.85 & 100.46 & & 0.85 & & & \\
\hline $2 \mathrm{R}-1,65-71$ & Olivine & 0.00 & 0.03 & 27.34 & 11.44 & 19.06 & 0.00 & 0.00 & 0.00 & 0.00 & 0.03 & 0.16 & 43.11 & 101.18 & & 0.84 & & & \\
\hline $2 \mathrm{R}-3,25-31$ & Olivine & 0.01 & 0.05 & 27.43 & 11.47 & 18.86 & 0.00 & 0.00 & 0.02 & 0.00 & 0.03 & 0.19 & 42.97 & 101.03 & & 0.84 & & & \\
\hline $2 \mathrm{R}-4,20-26$ & Olivine & 0.00 & 0.02 & 26.50 & 14.19 & 18.61 & 0.01 & 0.05 & 0.00 & 0.00 & 0.00 & 0.23 & 42.83 & 102.45 & & 0.81 & & & \\
\hline $2 \mathrm{R}-4,100-106$ & Olivine & 0.01 & 0.01 & 27.39 & 13.00 & 18.76 & 0.00 & 0.00 & 0.01 & 0.00 & 0.00 & 0.20 & 43.19 & 102.57 & & 0.83 & & & \\
\hline $2 \mathrm{R}-1,41-48$ & Orthopyroxene & 0.00 & 0.81 & 19.15 & 7.11 & 25.69 & 0.61 & 0.30 & 0.00 & 0.00 & 0.00 & 0.16 & 45.11 & 98.95 & & 0.86 & & & \\
\hline $1 \mathrm{R}-1,45-52$ & Plagioclase & 2.05 & 10.91 & 0.01 & 0.15 & 23.13 & 16.64 & 0.03 & 0.04 & 0.00 & 0.01 & 0.01 & 46.37 & 99.34 & 75 & & & & \\
\hline $2 \mathrm{R}-1,5-11$ & Plagioclase & 2.00 & 11.14 & 0.00 & 0.14 & 23.02 & 16.57 & 0.02 & 0.03 & 0.00 & 0.00 & 0.04 & 46.25 & 99.20 & 76 & & & & \\
\hline $2 \mathrm{R}-1,41-48$ & Plagioclase & 2.45 & 10.30 & 0.03 & 0.11 & 23.36 & 16.19 & 0.06 & 0.06 & 0.00 & 0.08 & 0.00 & 46.16 & 98.81 & 71 & & & & \\
\hline $2 \mathrm{R}-1,4 \mathrm{I}-48$ & Plagioclase & 2.22 & 10.78 & 0.01 & 0.14 & 23.28 & 16.33 & 0.06 & 0.02 & 0.00 & 0.04 & 0.00 & 46.29 & 99.18 & 74 & & & & \\
\hline $2 \mathrm{R}-1,41-48$ & Plagioclase & 1.92 & 11.34 & 0.02 & 0.11 & 22.94 & 16.79 & 0.01 & 0.02 & 0.02 & 0.00 & 0.03 & 46.40 & 99.60 & 77 & & & & \\
\hline $2 \mathrm{R}-1,65-71$ & Plagioclase & 2.20 & 10.83 & 0.04 & 0.08 & 23.29 & 16.34 & 0.01 & 0.05 & 0.00 & 0.02 & 0.00 & 46.29 & 99.14 & 74 & & & & \\
\hline $2 \mathrm{R}-3,25-31$ & Plagioclase & 2.09 & 11.23 & 0.00 & 0.11 & 22.89 & 16.70 & 0.03 & 0.04 & 0.08 & 0.01 & 0.02 & 46.28 & 99.48 & 76 & & & & \\
\hline $2 \mathrm{R}-3,71-77$ & Plagioclase & 2.30 & 10.37 & 0.01 & 0.12 & 23.23 & 16.83 & 0.04 & 0.02 & 0.04 & 0.00 & 0.02 & 46.46 & 99.44 & 72 & & & & \\
\hline $2 \mathrm{R}-4,20-26$ & Plagioclase & 2.35 & 10.40 & 0.00 & 0.17 & 23.58 & 16.72 & 0.07 & 0.04 & 0.02 & 0.00 & 0.00 & 46.82 & 100.17 & 72 & & & & \\
\hline $2 \mathrm{R}-4,100-106$ & Plagioclase & 1.89 & 11.41 & 0.01 & 0.10 & 22.41 & 17.51 & 0.05 & 0.05 & 0.00 & 0.00 & 0.02 & 46.41 & 99.86 & 78 & & & & \\
\hline $2 \mathrm{R}-4,20-26$ & Amphibole Field 1 & 1.67 & 8.37 & 10.61 & 4.82 & 21.19 & 5.40 & 2.14 & 0.23 & 0.00 & 0.03 & 0.09 & 42.73 & 97.27 & & & 1.50 & 0.39 & 0.67 \\
\hline $2 \mathrm{R}-1,5-11$ & Amphibole Field 1 & 1.82 & 8.74 & 10.11 & 5.27 & 20.91 & 5.91 & 1.69 & 0.17 & 0.00 & 0.01 & 0.06 & 42.61 & 97.30 & & & 1.56 & 0.31 & 0.72 \\
\hline $2 \mathrm{R}-4,100-106$ & Amphibole Field 1 & 1.97 & 8.21 & 10.76 & 4.56 & 20.81 & 6.07 & 1.62 & 0.28 & 0.24 & 0.01 & 0.05 & 42.61 & 97.19 & & & 1.60 & 0.29 & 0.80 \\
\hline $1 \mathrm{R}-1,45-52$ & Amphibole Field 1 & 2.20 & 8.02 & 9.79 & 5.56 & 20.12 & 6.24 & 2.64 & 0.36 & 0.17 & 0.01 & 0.08 & 42.39 & 97.58 & & & 1.77 & 0.48 & 0.91 \\
\hline \multicolumn{20}{|l|}{$153-921 \mathrm{E}-$} \\
\hline 8R-1,91-95 & Amphibole Field 2 & 0.9 & 7.72 & 7.78 & 13.8 & 23.018 & 2.589 & 0.6 & 0.2 & 0 & 0 & 0.2 & 41.5 & 98.363 & & & 0.73 & 0.11 & 0.40 \\
\hline $8 R-1,91-95$ & Amphibole Field 2 & 1 & 9.22 & 9.22 & 10.2 & 22.945 & 2.749 & 0.7 & 0 & 0 & 0 & 0.2 & 42.2 & 98.622 & & & 0.87 & 0.13 & 0.40 \\
\hline $8 \mathrm{R}-1,91-95$ & Amphibole Field 2 & 1.2 & 7.66 & 7.58 & 13.6 & 22.096 & 3.623 & 1 & 0.2 & 0.1 & 0 & 0.2 & 41.5 & 98.788 & & & 1.03 & 0.18 & 0.52 \\
\hline $8 \mathrm{R}-2,45-51$ & Amphibole Field 2 & 1.6 & 8.03 & 10 & 8.13 & 21.854 & 4.399 & 1.3 & 0.1 & 0.2 & 0 & 0.1 & 42.5 & 98.304 & & & 1.26 & 0.24 & 0.64 \\
\hline \multicolumn{20}{|l|}{$153-922 \mathrm{~A}$ - } \\
\hline $2 \mathrm{R}-1,65-71$ & Amphibole Field $3 \mathrm{Ax}$ & 0.1 & 9.24 & 14.1 & 2.28 & 27.573 & 0.075 & 0 & 0 & 0.1 & 0 & 0.2 & 45.3 & 98.878 & & & 0.00 & 0.00 & 0.02 \\
\hline $2 \mathrm{R}-3,71-77$ & Amphibole Field $3 \mathrm{Ax}$ & 0.2 & 8.86 & 13.8 & 3 & 26.484 & 0.224 & 0 & 0 & 0 & 0 & 0.1 & 43.9 & 96.559 & & & 0.10 & 0.00 & 0.06 \\
\hline $2 \mathrm{R}-4,100-106$ & Amphibole Field $3 \mathrm{Ax}$ & 0.2 & 8.6 & 13.8 & 3.83 & 26.529 & 0.275 & 0 & 0 & 0.1 & 0 & 0.2 & 44.2 & 97.715 & & & 0.13 & 0.00 & 0.07 \\
\hline $2 \mathrm{R}-4,20-26$ & Amphibole Field $3 A x$ & 0.3 & 9.16 & 13.1 & 3.8 & 26.385 & 0.71 & 0.1 & 0 & 0.1 & 0 & 0.1 & 44.3 & 98.037 & & & 0.19 & 0.01 & 0.11 \\
\hline $2 \mathrm{R}-3,71-77$ & Amphibole Field $3 \mathrm{Ax}$ & 0.2 & 8.93 & 14.1 & 2.56 & 26.49 & 0.885 & 0 & 0 & 0 & 0 & 0.1 & 44.6 & 97.872 & & & 0.22 & 0.00 & 0.07 \\
\hline $2 \mathrm{R}-3,71-77$ & Amphibole Field $3 \mathrm{Ay}$ & 1.2 & 8.37 & 9.92 & 8.53 & 23.351 & 3.839 & 0.1 & 0.1 & 0.1 & 0 & 0.1 & 42.9 & 98.407 & & & 0.86 & 0.01 & 0.45 \\
\hline $2 \mathrm{R}-3,71-77$ & Amphibole Field $3 \mathrm{Ay}$ & 1.3 & 8.12 & 9.9 & 8.56 & 23.257 & 3.939 & 0.1 & 0 & 0 & 0.1 & 0.2 & 42.8 & 98.208 & & & 0.88 & 0.01 & 0.49 \\
\hline $2 \mathrm{R}-3,71-77$ & Amphibole Field $3 \mathrm{Ay}$ & 1.4 & 8.34 & 9.71 & 8.67 & 22.726 & 4.382 & 0.2 & 0.1 & 0 & 0.1 & 0.1 & 42.7 & 98.375 & & & 1.02 & 0.03 & 0.55 \\
\hline $2 \mathrm{R}-3,71-77$ & Amphibole Field $3 \mathrm{~B}$ & 2.1 & 8.71 & 7.72 & 10.9 & 20.323 & 6.85 & 0 & 0.1 & 0 & 0.2 & 0.2 & 41.8 & 98.872 & & & 1.62 & 0.01 & 0.82 \\
\hline $1 \mathrm{R}-1,45-52$ & Amphibole Field 3B & 1.9 & 8.52 & 7.98 & 8.84 & 20.177 & 7.785 & 0.1 & 0.1 & 0 & 0.1 & 0.1 & 41.9 & 97.518 & & & 1.69 & 0.01 & 0.76 \\
\hline $2 \mathrm{R}-1,65-71$ & Amphibole Field 3B & 2.3 & 8.72 & 7.83 & 9.08 & 20.062 & 7.7 & 0.1 & 0.1 & 0 & 0.7 & 0.2 & 41.9 & 98.614 & & & 1.72 & 0.01 & 0.89 \\
\hline $2 \mathrm{R}-1,1-8$ & Chlorite & 0 & 0.02 & 15.9 & 9.07 & 13.849 & 10.314 & 0 & 0 & 0 & 0 & 0.2 & 38.1 & 87.95 & & & & & \\
\hline $1 \mathrm{R}-1,45-52$ & Chlorite & 0 & 0.04 & 15.9 & 8.73 & 13.947 & 10.37 & 0 & 0 & 0.1 & 0 & 0.1 & 38.2 & 87.875 & & & & & \\
\hline $1 \mathrm{R}-1,45-52$ & Chlorite & 0 & 0.05 & 15.8 & 8.58 & 13.935 & 10.313 & 0 & 0 & 0 & 0 & 0.2 & 38 & 87.316 & & & & & \\
\hline IR-1, 45-52 & Chlorite & 0 & 0.04 & 16.1 & 8.73 & 13.878 & 10.126 & 0 & 0 & 0 & 0 & 0.2 & 38 & 87.556 & & & & & \\
\hline $2 \mathrm{R}-1,65-71$ & Chlorite & 0 & 0.02 & 16 & 8.68 & 13.966 & 10.315 & 0 & 0 & 0 & 0 & 0.1 & 38.2 & 87.812 & & & & & \\
\hline IR-1, 45-52 & Chlorite & 0 & 0.05 & 16 & 8.59 & 13.745 & 10.527 & 0 & 0 & 0 & 0 & 0.2 & 38.1 & 87.766 & & & & & \\
\hline
\end{tabular}

Figure 2. Complete amphibolitization of olivine and extensive development of chloritic halo. Contact between chlorite and fibrous actinolite is the former primary contact between olivine and plagioclase. The contact is remarkably straight, suggesting that chlorite and actinolite are in equilibrium. In contrast, the contact between colorless feldspar and chlorite is sutured, evidence of disequilibrium and replacement of feldspar by chlorite. Sample $153-922 \mathrm{~A}-2 \mathrm{R}-4,20-26 \mathrm{~cm}$. Field length is 2 $\mathrm{mm}$. Core axis is parallel to the short axis of photograph, and the uphole direction is toward the top of the photograph.

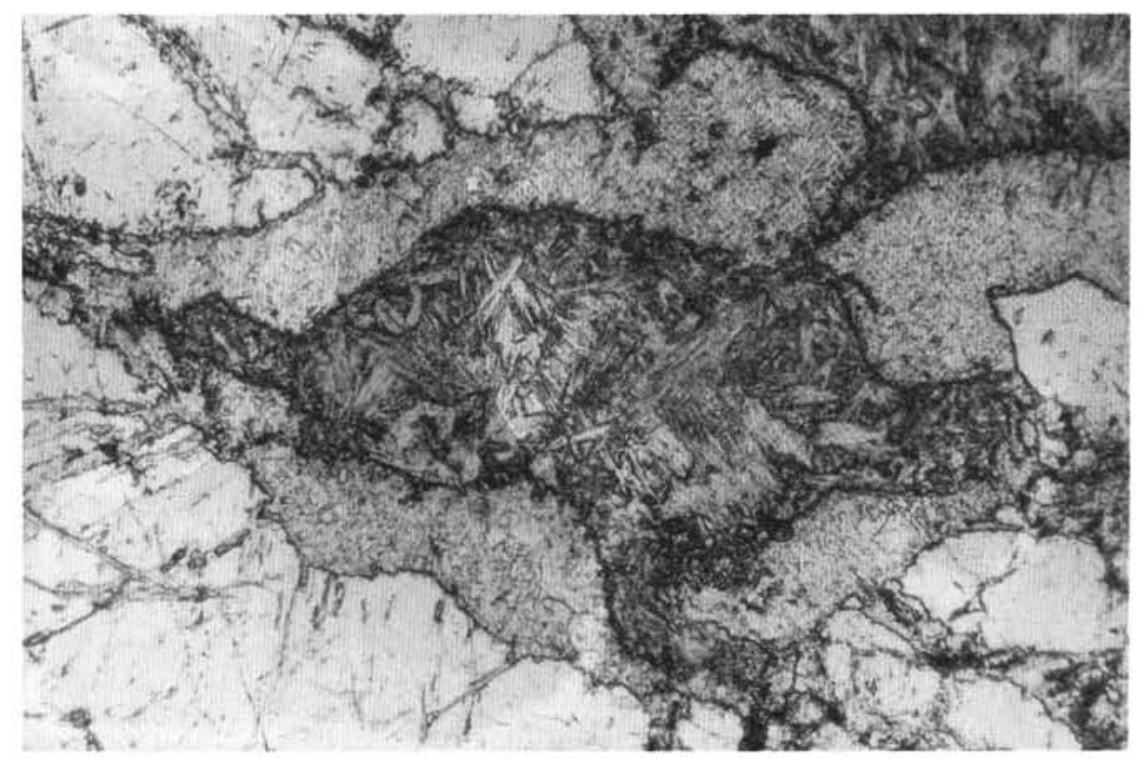




\section{A}

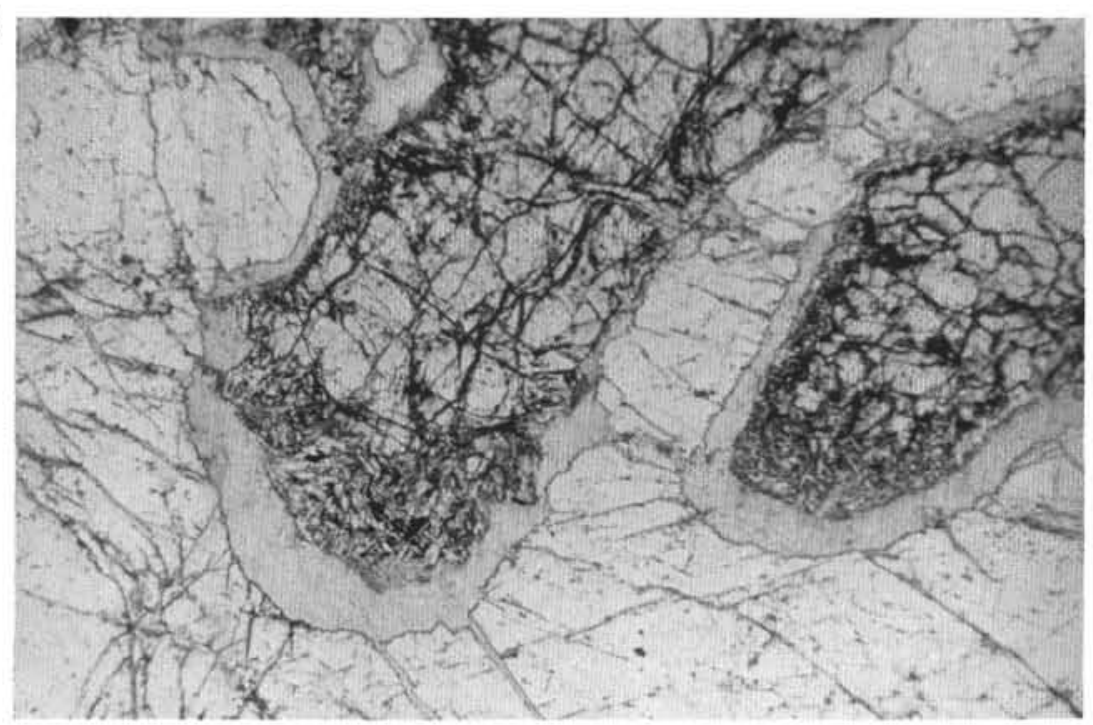

B

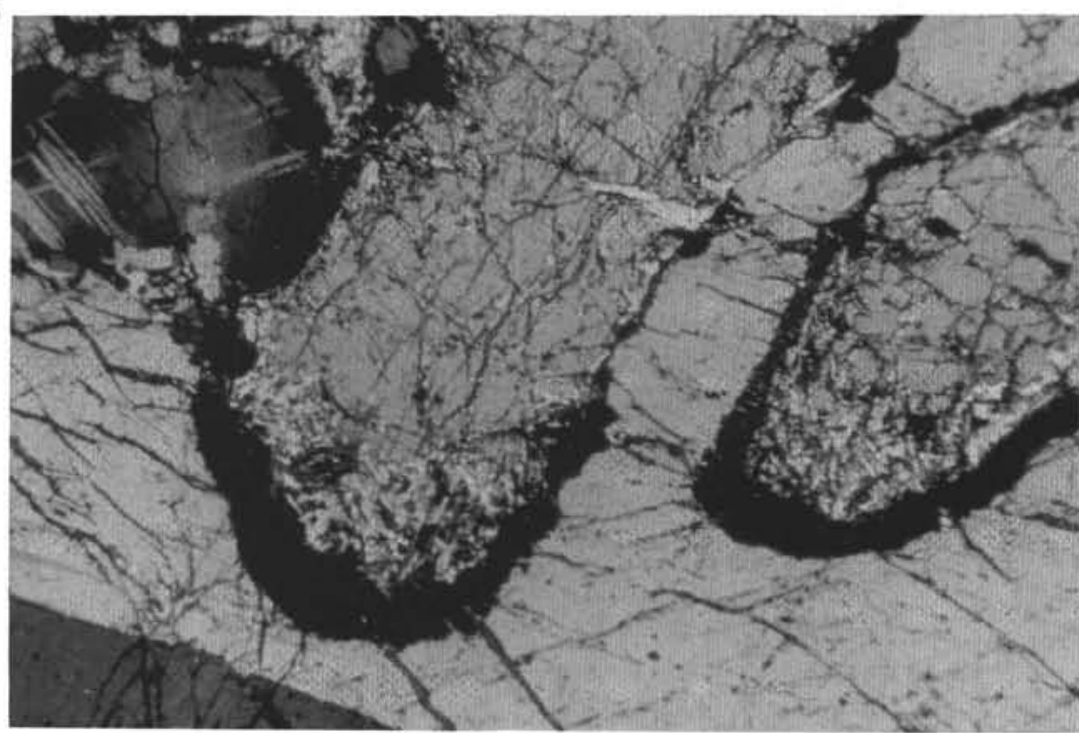

Figure 3. Incipient amphibolitization and development of achloritic halo. A. Plane-polarized light. B. Crosspolarized light. Olivine grains are more strongly replaced by actinolite near the blunt terminations of the grains. The chloritic halo is thickest in areas adjacent to the portions of olivine grains that are most strongly replaced by amphibole. Sample 153-922A-3R-1, 59-63 $\mathrm{cm}$. Field length is $4 \mathrm{~mm}$. Core axis is parallel to the short axis of photograph, and the uphole direction is toward the top of the photograph.

\section{MODAL MINERALOGY AND REACTION PATHS}

Troctolitic gabbro from Hole 922A shows systematic variations in modal mineralogy with degree of alteration (Table 2). Degree of alteration is best defined by the abundance of chlorite and actinolite, which form the dominant products of alteration. Talc is not present in large quantities in any sample, but seems to be more abundant in weakly altered samples. As indicated by reaction textures, olivine and plagioclase are the dominant reactant phases, and the abundance of both decreases with higher degrees of alteration. In fact, olivine is completely absent in the highly altered samples. In contrast, pyroxene and Field 1 amphibole show no systematic variation in modal abundance with degree of alteration. Accessory phases include calcite, apatite, quartz, pyrite, magnetite, ilmenite, anthophyllite, and pyrophyllite.

Amphibole populations not only show strong increases in abundance but also systematic changes in composition with degree of alteration. In weakly altered samples, normalized histograms of the tetrahedral aluminum content are bimodal, and show a strong peak on pargasitic hornblende compositions (Fig. 6A). Amphibole compositions are also bimodal in moderately altered samples, but actinolitic compositions dominate (Fig. 6B). In highly altered samples, the composition histograms have a single peak on actinolitic compositions (Fig. 6C).
Changes in the molecular abundance of the dominant primary and secondary phases define reaction paths of progressive alteration (Fig. 7). Textural evidence outlined above indicates that actinolite predominately replaced olivine, and chlorite predominately replaced plagioclase. However, the strong linear correlation between the molecular abundances of feldspar and olivine and of actinolite and chlorite suggests that the two reactions operated simultaneously in weakly and moderately altered samples (Fig. 7). In the more advanced stages of alteration, we interpret the reaction paths to curve (Fig. 7). Textural evidence suggests that, after olivine is completely consumed, amphibole with compositions that plot in Field 3Ay (Fig. 4) were produced at the expense of plagioclase. The only other reactions that could have accompanied this late replacement of plagioclase by amphibole are exchange reactions that depleted $\mathrm{Mg}$ content in the existing amphibole population.

\section{WHOLE-ROCK GEOCHEMISTRY}

Major-element compositions of samples from the suite of variably altered troctolite show very little systematic variations with degree of alteration (Table 3 ). The main chemical change that can be confidently attributed to alteration is the strong increase in material lost on ignition, which we interpret to be predominately $\mathrm{H}_{2} \mathrm{O}$. Silicon, magne- 

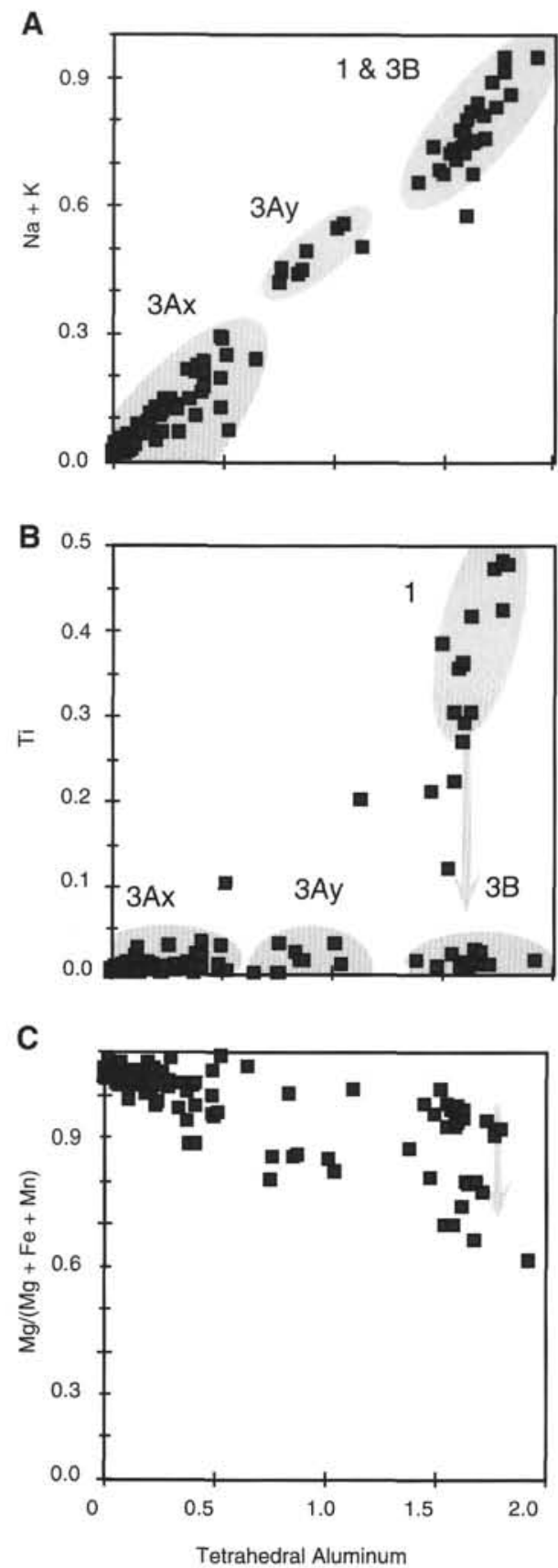

Figure 4. Compositional variations in amphibole from troctolitic gabbro of Hole $922 \mathrm{~A} ; \mathrm{n}=112$. A. Tetrahedral aluminum is plotted vs. sodium + potassium. B. Tetrahedral aluminum is plotted vs. titanium. C. Tetrahedral aluminum is plotted vs. the ratio of magnesium to (magnesium + iron + manganese). Amphiboles in Field 1 are primary. Amphiboles in Field 3Ax are secondary and replace olivine. Amphiboles in Field $3 \mathrm{Ay}$ are secondary and replace feldspar. Amphiboles in Field 3B are altered primary amphiboles.

sium, calcium, and sodium show weak depletions in highly altered samples. Iron shows a slightly stronger depletion in the highly altered samples (Table 3).

\section{MASS BALANCE OF HYDROTHERMAL ALTERATION}

To define element mobility of the hydrothermal alteration, balanced reactions must be calculated that use representative composi-

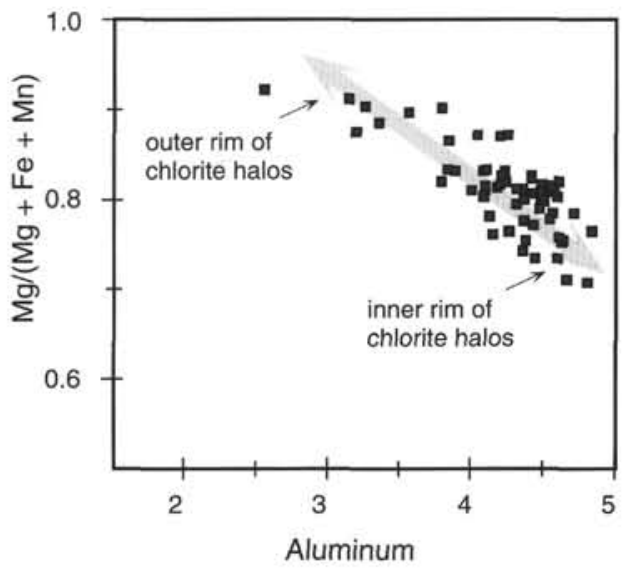

Figure 5. Compositional variation in chlorite. Chloritic halos are compositionally zoned and contain more $\mathrm{Mg}$-rich chlorite along the inner rim.

tions of the primary phases and reproduce relative changes in (1) modal abundance of primary and secondary phases and (2) wholerock geochemistry. Following the terminology of Thompson (1982) and Spear (1993), the chemical system of the altered troctolite is defined in terms of phase components and system components. The dominant mineral-phase components of the altered troctolite system include plagioclase, olivine, chlorite, and actinolite. These phases are composed of seven main system components: $\mathrm{NaO}_{1 / 2}, \mathrm{CaO}, \mathrm{MgO}$, $\mathrm{FeO}, \mathrm{SiO}_{2}, \mathrm{AlO}_{3 / 2}$, and $\mathrm{H}_{2} \mathrm{O}$. Other oxide components, such as $\mathrm{KO}_{1 / 2}$, $\mathrm{TiO}_{2}$, and $\mathrm{MnO}$, occur in minor quantities and are ignored in the chemical system. To investigate all possibilities of element mobility, the chemical system is assumed to be open to all system components. Therefore, each of the seven system components must also be phase components as listed in Table 4. Mass transfer in any system with 11 phase components and 7 system components is completely described by combinations of 4 linearly independent reactions. However, the combinatorial formula shows that there are 165 possible linear combinations of these 4 reactions (e.g., Spear and Peacock, 1989).

Table 5 shows some of the possible reactions that convert plagioclase to chlorite, and olivine to actinolite. Reactions 1, 2, and 3 are balanced to conserve $\mathrm{Mg}, \mathrm{Fe}$, and $\mathrm{Si}$, respectively, in the reaction of olivine to actinolite. Reactions 4, 5, 6, and 7 are balanced to conserve $\mathrm{Si}, \mathrm{Al}, \mathrm{Ca}$, and $\mathrm{Na}$, respectively, in the reaction of feldspar to chlorite. Reaction 8 is a linear combination of reactions 3 and 5 that fits the number of moles of feldspar and olivine destroyed and the number of moles of chlorite and actinolite created in $10,000 \mathrm{~cm}^{3}$ of highly altered troctolite. Approximately $5 \mathrm{~mol}$ of actinolite and chlorite are created before the reaction curve flattens (Fig. 7B), and approximately $40 \mathrm{~mol}$ of olivine are consumed for every $15 \mathrm{~mol}$ of feldspar (Fig. $7 \mathrm{~A})$.

The stoichiometry of reaction 8 also crudely fits the observed changes in major-element composition in the suite of variably altered troctolite (Table 6). Observed changes were calculated simply by subtracting the average bulk composition of the four highly altered samples from that of the three weakly altered samples (Table 3). Modeled changes in the oxide weight abundances were calculated assuming that major elements were transported in and out of the system in proportions defined by the stoichiometry of reaction 8 (Table 4). In these calculations, it was also necessary to assume that the density of highly altered troctolite is $2.85 \mathrm{~g} / \mathrm{cm}^{3}$ (e.g., Shipboard Scientific Party, 1995). The signs of the observed and modeled changes in oxides are the same for all major elements except $\mathrm{MgO}$ (Table 6). Additionally, the magnitude of observed changes fits very well the magnitude of modeled changes in $\mathrm{NaO}, \mathrm{CaO}, \mathrm{Al}_{2} \mathrm{O}_{3}$, and $\mathrm{H}_{2} \mathrm{O}$. The most significant differences between observed and modeled changes are found in $\mathrm{FeO}, \mathrm{MgO}$, and $\mathrm{SiO}_{2}$. Factors that are important in producing these discrepancies are discussed in the following section. 
Table 2. Modal mineralogy determined from microprobe-generated point counts.

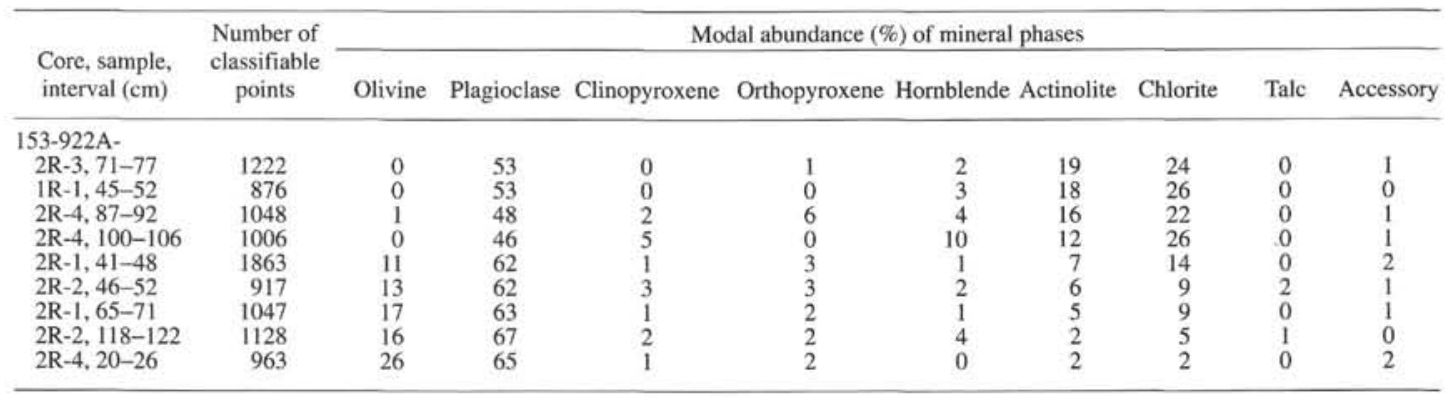

A

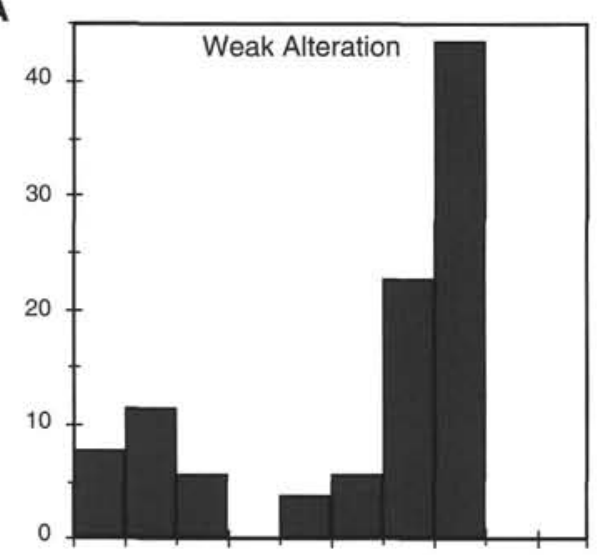

B
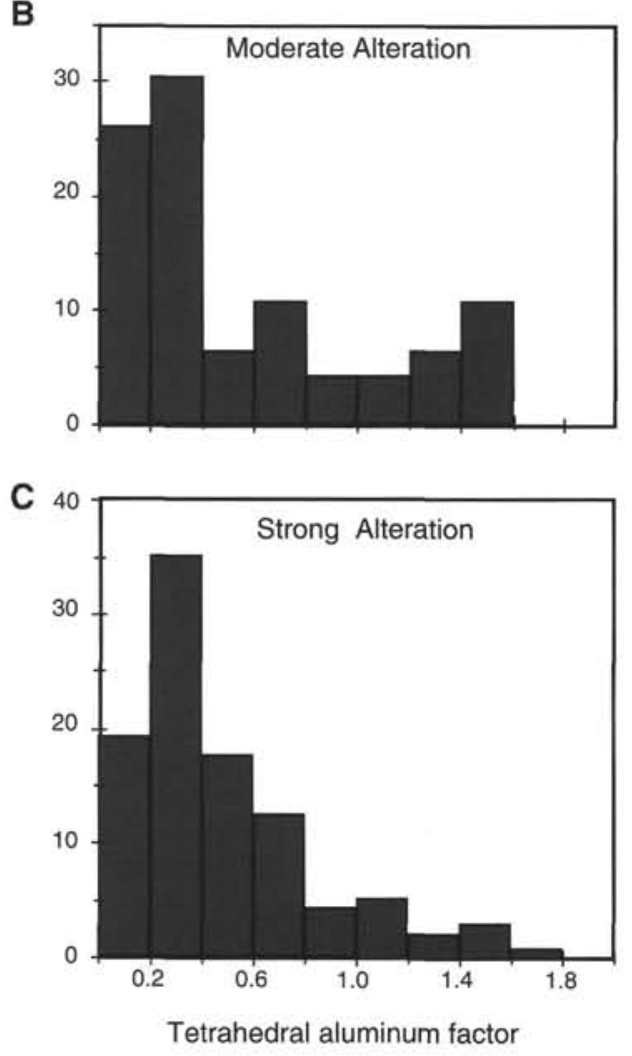

Figure 6. Compositional variability among amphibole populations. A. Weak alteration, Sample 153-922A-2R-2, 118-122 cm. B. Moderate alteration, Sample 153-922A-2R-1, 65-71 cm. C. Strong alteration, Sample 153-922A$2 \mathrm{R}-3,71-77 \mathrm{~cm}$. Tetrahedral aluminum compositions were determined by calculating structural formulas from the point-counting analyses described in the "Methods" section, this chapter.
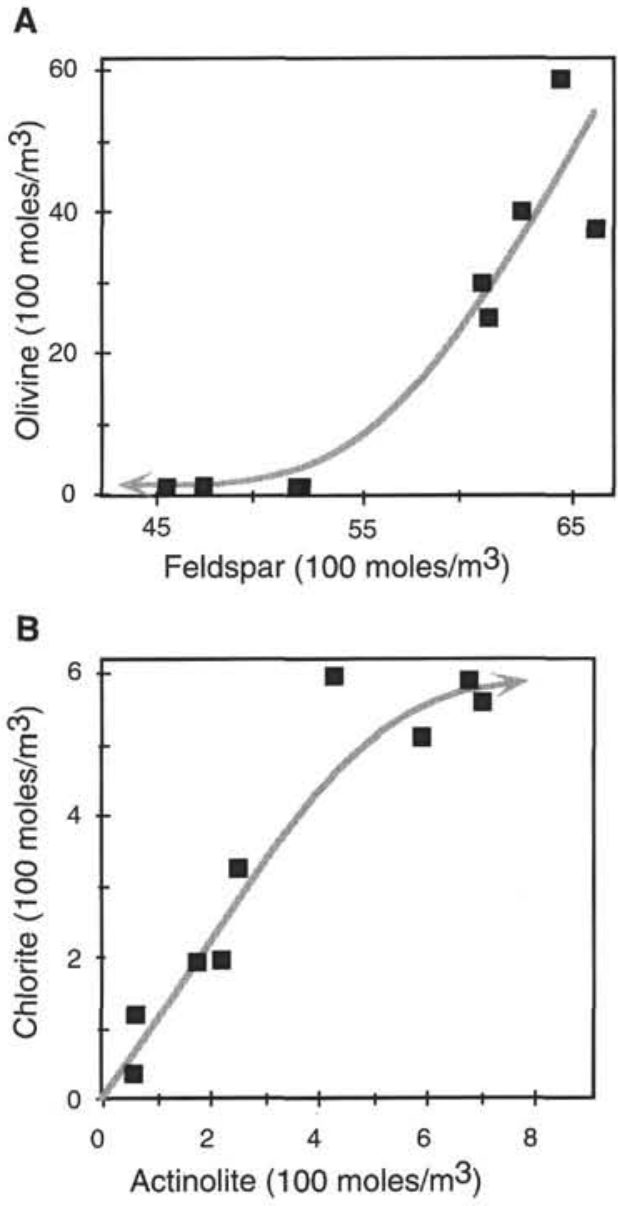

Figure 7. Reaction paths for (A) primary and (B) secondary phases. Molecular abundance was determined by dividing modal abundance by molar volume of the magnesium or calcium end members of each phase. Molar volumes are listed in Robie and Waldbaum (1968).

\section{DISCUSSION}

Greenschist facies hydrothermal alteration of troctolitic rocks from Site 922 is dominated by two main reactions: plagioclase to chlorite, and olivine to actinolite. Although we cannot completely rule out the possibility that the rocks were affected by two completely different episodes of alteration, several lines of evidence suggest that both reactions occurred simultaneously in one alteration event. The two dominant alteration products, chlorite and actinolite, are always spatially associated in the rock, and form coronitic replacement textures. A strong linear correlation is observed in the relative abundance of actinolite and chlorite from different, variably altered samples (Fig. 7). Additionally, this correlation is observed at a much 
Table 3. Major-element compositions of variably altered troctolite.

\begin{tabular}{|c|c|c|c|c|c|c|c|c|c|c|c|c|c|}
\hline \multirow{2}{*}{$\begin{array}{l}\text { Core, section, } \\
\text { interval }(\mathrm{cm})\end{array}$} & \multirow[b]{2}{*}{ Alteration } & \multicolumn{12}{|c|}{ Major element composition (wt\%) } \\
\hline & & $\mathrm{SiO}_{2}$ & $\mathrm{TiO}_{2}$ & $\mathrm{Al}_{2} \mathrm{O}_{3}$ & $\mathrm{Fe}_{2} \mathrm{O}_{3}$ & $\mathrm{MnO}$ & $\mathrm{MgO}$ & $\mathrm{CaO}$ & $\mathrm{Na}_{2} \mathrm{O}$ & $\mathrm{K}_{2} \mathrm{O}$ & $\mathrm{P}_{2} \mathrm{O}_{5}$ & LOI & Total \\
\hline \multicolumn{14}{|l|}{$153-922 \mathrm{~A}$ - } \\
\hline $2 \mathrm{R}-3,71-77$ & High & 45.79 & 0.19 & 20.12 & 4.62 & 0.08 & 12.59 & 10.84 & 1.69 & 0.07 & 0.05 & 3.76 & 99.80 \\
\hline $1 \mathrm{R}-1,45-52$ & High & 44.34 & 0.12 & 20.77 & 5.14 & 0.10 & 13.09 & 10.44 & 1.76 & 0.04 & 0.02 & 3.76 & 99.58 \\
\hline $2 \mathrm{R}-4,100-106$ & High & 44.84 & 0.22 & 18.33 & 5.78 & 0.08 & 14.03 & 10.76 & 1.38 & 0.05 & 0.09 & 3.98 & 99.54 \\
\hline $2 \mathrm{R}-1,1-8$ & High & 44.71 & 0.10 & 19.81 & 4.99 & 0.10 & 13.96 & 11.02 & 1.41 & 0.05 & 0.02 & 4.30 & 100.47 \\
\hline $2 \mathrm{R}-1,41-48$ & Moderate & 46.80 & 0.16 & 20.44 & 4.48 & 0.06 & 11.60 & 11.85 & 1.88 & 0.08 & 0.02 & 2.49 & 99.86 \\
\hline $2 \mathrm{R}-2,46-52$ & Moderate & 45.58 & 0.15 & 19.75 & 5.25 & 0.08 & 14.45 & 10.79 & 1.77 & 0.05 & 0.02 & 1.83 & 99.72 \\
\hline $2 \mathrm{R}-1,65-71$ & Moderate & 44.92 & 0.05 & 19.62 & 5.45 & 0.08 & 14.89 & 10.80 & 1.56 & 0.06 & 0.02 & 2.18 & 99.63 \\
\hline $2 \mathrm{R}-2,118-122$ & Low & 46.17 & 0.27 & 19.86 & 5.76 & 0.09 & 13.68 & 11.04 & 2.00 & 0.05 & 0.08 & 1.03 & 100.03 \\
\hline $2 \mathrm{R}-4,20-26$ & Low & 46.30 & 0.46 & 19.90 & 6.62 & 0.10 & 11.76 & 11.64 & 2.08 & 0.04 & 0.04 & 0.95 & 99.89 \\
\hline $2 \mathrm{R}-3,25-31$ & Low & 45.98 & 0.17 & 19.31 & 5.83 & 0.09 & 15.34 & 10.43 & 1.78 & 0.07 & 0.04 & 0.73 & 99.77 \\
\hline
\end{tabular}

Note: $\mathrm{LOI}=$ loss on ignition .

Table 4. Phase components and system components of altered troctolite.

\begin{tabular}{|c|c|c|c|c|c|c|c|}
\hline \multirow[b]{2}{*}{ Phase components } & \multicolumn{7}{|c|}{ System components } \\
\hline & $\mathrm{NaO}_{1 / 2}$ & $\mathrm{CaO}$ & $\mathrm{MgO}$ & $\mathrm{FeO}$ & $\mathrm{SiO}_{2}$ & $\mathrm{AlO}_{3 / 2}$ & $\mathrm{H}_{2} \mathrm{O}$ \\
\hline Olivine & 0.00 & 0.00 & 1.68 & 0.31 & 1.00 & 0.00 & 0 \\
\hline Plagioclase & 0.25 & 0.75 & 0.00 & 0.01 & 2.28 & 1.71 & 0 \\
\hline Actinolite & 0.07 & 1.84 & 4.77 & 0.38 & 7.78 & 0.27 & 1 \\
\hline Chlorite & 0.01 & 0.01 & 7.74 & 1.82 & 5.84 & 4.49 & 8 \\
\hline $\mathrm{NaO}_{12}$ & 1 & 0 & 0 & 0 & 0 & 0 & 0 \\
\hline $\mathrm{CaO}^{1 / 2}$ & 0 & i & 0 & 0 & 0 & 0 & 0 \\
\hline $\mathrm{MgO}$ & 0 & 0 & 1 & 0 & 0 & 0 & 0 \\
\hline $\mathrm{FeO}$ & 0 & 0 & 0 & 1 & 0 & 0 & 0 \\
\hline $\mathrm{SiO}_{2}$ & 0 & 0 & 0 & 0 & 1 & 0 & 0 \\
\hline $\mathrm{AlO}_{3 / 2}$ & 0 & 0 & 0 & 0 & 0 & 1 & 0 \\
\hline $\mathrm{H}_{2} \mathrm{O}$ & 0 & 0 & 0 & 0 & 0 & 0 & 1 \\
\hline
\end{tabular}

smaller scale around partially replaced olivine grains (Fig. 3). Most importantly, a single balanced reaction reproduces reasonably well the changes in whole-rock geochemistry and modal mineralogy in variably altered samples.

The variation in bulk composition in the suite of samples is interpreted to predominantly reflect (1) analytical error of the chemical analyses, (2) magmatic evolution of the protolith, and, of course, (3) element fluxes of hydrothermal alteration. The observed changes in bulk composition are small and near the detectable limits of the analyses. However, the coincidence of observed and modeled changes of most of the major elements that were modeled in this study suggests that these changes could be real variations. As presented above, similarities in primary igneous grain size, texture, and phase composition suggest that effects of the latter were minimized, which was an objective of the sampling strategy. However, we cannot rule out the possibility that some of the differences between observed and modeled changes in composition (Table 6) are the result of magmatic evolution of the protolith. Because the modeled changes are only based on the stoichiometry of Reaction 8 , other alteration reactions could also be responsible for discrepancies between observed and modeled changes. For example, the breakdown of titanomagnetite to titanite and rutile is observed in other hydrothermally altered oceanic rocks (e.g., Laverne et al., 1995) and could have produce the additional observed depletion of $\mathrm{FeO}$ (Table 6). The presence of titanite in the altered troctolites of this study supports this interpretation.

The pattern of major-element enrichment of hydrothermal water relative to seawater is largely antithetic to the relative enrichments recorded by altered troctolitic gabbros in this study (e.g., Campbell et al. 1988; Campbell and Edmund, 1989; Von Damm, 1990). Estimations of the magnitude of relative enrichments of some of the major elements in hydrothermal water discharged in the TAG and MARK areas are $1.9 \mathrm{mmol} \mathrm{kg}^{-1}, 19.3 \mathrm{mmol} \mathrm{kg}-1,70.3 \mathrm{mmol} \mathrm{kg}-1,5.3 \mathrm{mmol}$ $\mathrm{kg}^{-1}$, and $-52.7 \mathrm{mmol} \mathrm{kg}^{-1}$ for $\mathrm{Fe}, \mathrm{Si}, \mathrm{Na}, \mathrm{Ca}$, and $\mathrm{Mg}$, respectively (Von Damm, 1990). Aluminum is typically elevated in hydrothermal water, but magnitudes were not reported by Von Damm (1990). Of the element enrichments modeled in the altered troctolite, aluminum is the only one that is not antithetic to enrichments in hydrothermal water. Therefore, it is likely that the observed hydrothermal alteration of troctolitic rocks in this study occurred in the root zone of such hydrothermal vents.

Water:rock ratios can be calculated using the above enrichment factors for hydrothermal water and altered troctolite (Table 7). Like all calculations of relative volumes of water:rock interactions, assumptions must be made about the flow path and composition of hydrothermal fluids. One-dimensional drill cores contain limited information about the larger-scale three-dimensional character of hydrothermal circulation. Therefore, water:rock ratios were calculated assuming the simplest possible path that could have affected these rocks: the direct inflow of seawater and outflow of hydrothermal water (Table 7). Seawater and hydrothermal water compositions were obtained from in situ measurements by Campbell et al. (1988) and Campbell and Edmund (1989), which are summarized by Von Damm (1990). It is assumed that the difference in composition of the two types of water is produced by ion exchange with the troctolite during hydrothermal alteration.

The modeled reaction 8 requires element mobility because the coefficients of nearly all oxide-phase components are nonzero (Table 5). Assuming the simple flow path and exchange scenario described above, water:rock ratios vary from 0 to 36 for samples in which reaction 8 has gone to completion (Table 7). These ratios are within the range of values calculated for other altered portions of ophiolites and in situ oceanic crust (e.g., Gregory and Taylor, 1981; Stakes and O’Neil, 1982; Mottl, 1983; Lécuyer et al., 1990). It is also possible to calculate water:rock ratios assuming that all of the measured changes in bulk composition are caused by a similar exchange with hydrothermal fluids (Table 7). These ratios are much more highly variable, and may erroneously reflect other factors that contribute to the observed chemical variation, such as analytical error and primary magmatic variation. We argue below that the highest estimates, based on relative depletions of $\mathrm{Fe}, \mathrm{Si}$, and $\mathrm{Ca}$, could be significantly lower if more complex circulation paths are considered. Therefore, we consider water:rock ratios $<10$ to be more realistic.

Based on the metamorphic grade and the pattern of element enrichments in the troctolite, we infer that it was altered in the deeper levels of the hydrothermal system. At shallow levels $(<1 \mathrm{~km})$ and recharge zones, oceanic rocks commonly show a gain of $\mathrm{Na}$, and $\mathrm{Mg}$, and a loss of Ca (e.g., Alt et al., 1986; Harper et al., 1988; Lécuyer et al., 1990). Oceanic rocks in discharge zones, however, are commonly epidotized, and show a gain of $\mathrm{Ca}, \pm \mathrm{Fe}, \pm \mathrm{Al}$, and a loss of $\mathrm{Mg}$ (e.g., Harper et al., 1988; Nehlig, 1994). Neither of these patterns fit the alteration observed in the troctolites. At about the base of the sheeted dike complex in the Trinity ophiolite, Lécuyer et al. (1990) document an important reversal in the enrichment pattern of $\mathrm{Al}$ and $\mathrm{Si}$. Below this level, rocks record a gain of $\mathrm{Al}$ and a loss of $\mathrm{Si}$, which is compat- 
Table 5. Phase coefficients for balanced system reactions.

\begin{tabular}{|c|c|c|c|c|c|c|c|c|c|c|c|}
\hline Reaction & Olivine & Plagioclase & Actinolite & Chlorite & $\mathrm{MgO}$ & $\mathrm{FeO}$ & $\mathrm{SiO}_{2}$ & $\mathrm{NaO}_{1 / 2}$ & $\mathrm{CaO}$ & $\mathrm{AlO}_{3 / 2}$ & $\mathrm{H}_{2} \mathrm{O}$ \\
\hline 1 & 2.8 & & -1.0 & & & -0.5 & 4.9 & 0.1 & 1.8 & 0.3 & 1 \\
\hline 2 & 1.2 & & -1.0 & & 2.7 & & 6.5 & 0.1 & 1.8 & 0.3 & i \\
\hline 3 & 7.8 & & -1.0 & & -8.3 & -2.0 & & 0.1 & 1.8 & 0.3 & 1 \\
\hline 4 & & 10.2 & & -4.0 & 30.9 & 7.2 & & -2.5 & -7.7 & 0.5 & 32 \\
\hline 5 & & 10.5 & & -4.0 & 30.9 & 7.2 & -0.6 & -2.6 & -7.9 & & 32 \\
\hline 6 & & 0.0 & & -4.0 & 31.0 & 7.3 & 23.3 & 0.0 & & 17.9 & 32 \\
\hline 7 & & 0.1 & & -4.0 & 31.0 & 7.3 & 23.2 & & 0.0 & 17.8 & 32 \\
\hline \multicolumn{12}{|c|}{ Reaction fitting product-reactant ratios (combination of 3,5 ) } \\
\hline 8 & 40.2 & 15.1 & -5.2 & -5.7 & 1.4 & 0.0 & -0.9 & -3.4 & -1.9 & 1.4 & 51.1 \\
\hline
\end{tabular}

Note: Compositions of phases are listed in Table 4.

Table 6. Changes in oxide weight percentage.

\begin{tabular}{lrrrrrrr}
\hline & \multicolumn{7}{c}{ Change in oxide weight percentage (g/a) } \\
\cline { 2 - 7 } & $\mathrm{Na}_{2} \mathrm{O}$ & $\mathrm{CaO}$ & $\mathrm{MgO}$ & $\mathrm{FeO}$ & $\mathrm{SiO}_{2}$ & $\mathrm{Al}_{2} \mathrm{O}_{3}$ & $\mathrm{H}_{2} \mathrm{O}$ \\
\hline Observed & -0.39 & -0.27 & -0.18 & -0.85 & -1.23 & 0.07 & 3.05 \\
Modeled & -0.37 & -0.37 & 0.20 & 0.00 & -0.19 & 0.25 & 3.22 \\
\hline
\end{tabular}

Notes: Observed changes are differences between average bulk composition of the fou highly altered samples and that of the three weakly altered samples (Table 3 ). Modeled changes in the oxide weight abundances were calculated assuming that major elements were transported in and out of the system in proportions defined by the stoichiometry of reaction 8 (Table 4 ).

ible with the style of alteration observed in the troctolites in this study (Table 7). Significantly lower water:rock ratios would be required to produce the depletion of $\mathrm{Fe}, \mathrm{Si}$, and $\mathrm{Ca}$ (Table 7) if fluids that left the troctolite system interacted with rock in a discharge zone before expulsion through a hydrothermal vent.

The strong spatial association of alteration with fractures and veins suggests that they acted as conduits for fluid flow. Hydrothermal circulation is commonly thought to be predominately driven by elevated heat flow above magma chambers (e.g., Lister, 1977, 1988). However, in fault zones like that found in the MARK area, pressure gradients created by the opening of cracks and veins could be equally important driving forces of fluid flow.

\section{CONCLUSIONS}

1. The nearly continuous range in amphibole compositions from pargasite to actinolite in gabbroic rocks from Leg 153 reflects progressive unroofing in the footwall of a brittle-ductile normal fault. The degree of disequilibrium between preexisting minerals and secondary minerals increases as the contents of titanium and aluminum of the secondary amphibole decrease. The highest degrees of alteration produced a greenschist facies assemblage of actinolitic amphibole + chlorite \pm talc \pm epidote \pm prehnite \pm pyrite \pm quartz \pm titanite.

2. The two dominant reactions that affected troctolitic gabbro of Hole $922 \mathrm{~A}$ are olivine to actinolite and plagioclase to chlorite. Coronitic reaction textures and strong linear correlations of increases in modal abundance of chlorite and actinolite and decreases in modal abundances of plagioclase and olivine suggest that the two reactions operated simultaneously, and mutually supplied necessary reactants to the two types of alteration sites.

3. In the most highly altered samples, amphibole continued to form at the expense of plagioclase after olivine was completely consumed. The amphibole that replaced plagioclase contains higher aluminum and alkali content than the amphibole that replaced olivine but both contain almost no Ti. It is possible that the latest change in amphibole composition was
Table 7. Maximum estimates of water:rock ratio.

\begin{tabular}{lccccc}
\hline & \multicolumn{5}{c}{ Maximum water:rock ratio } \\
\cline { 2 - 6 } & $\mathrm{MgO}$ & $\mathrm{FeO}$ & $\mathrm{SiO}_{2}$ & $\mathrm{Na}_{2} \mathrm{O}$ & $\mathrm{CaO}$ \\
\hline Reaction 8 & 3 & 0 & 5 & 10 & 36 \\
Bulk composition & 5 & 396.05 & 60 & 10 & 52 \\
\hline
\end{tabular}

Notes: Ratios were calculated assuming direct inflow of seawater and outflow of hydrothermal water. Seawater and hydrothermal water compositions were obtained from in situ measurements by Campbell et al. (1988), and Campbell and Edmond (1989), which are summarized by Von Damm (1990).

caused by the change in host grain of alteration rather than by a change in pressure or temperature.

4. The dominant metasomatic change associated with greenschist facies hydrothermal alteration was the addition of water; approximately $5110 \mathrm{~mol} / \mathrm{m}^{3}$ were added to the most highly altered troctolitic gabbro. This corresponds to a $3 \%$ increase in material lost on ignition (LOI) that we assume to be predominantly chemically bound water. Other observed and predicted changes in major-element chemistry are small $(<1 \%)$, and arguably would not be detectable in the suite of variably altered samples. It is worth noting, however, that the observed and modeled changes of major elements in the altered troctolite are largely antithetic to enrichment patterns observed in submarine hydrothermal water relative to seawater. Therefore, alteration could have occurred in the root zone of such hydrothermal systems.

\section{ACKNOWLEDGMENTS}

This study would not have been possible without discussions and advice from Dan Barnet, John Bowman, Mathilde Cannat, and John Bartley. Ray Lambert and Bill Nash provided many hours to help design the point-counting procedure. The paper significantly benefited from careful reviews by Christine Laverne, Jonathan Snow, Mathilde Cannat, and Jeff Karson. Guillermo Rubio and Gabriel Rendon provided many hours of creative technical support to process samples used in this study.

\section{REFERENCES}

Alt, J.C., Honnorez, J., Laverne, C., and Emmermann, R., 1986. Hydrothermal alteration of a $1 \mathrm{~km}$ section through the upper oceanic crust, Deep Sea Drilling Project Hole 504B: mineralogy, chemistry, and evolution of seawater-basalt interactions. J. Geophys. Res., 91:10309-10335.

Bartley, J.M., Fletcher, J.M., and Glazner, A.F., 1990. Tertiary extension and contraction of lower plate rocks in the Central Mojave Metamorphic Core Complex, southern California. Tectonics, 9:521-534.

Campbell, A.C., and Edmond, J.M., 1989. Halide systematics of submarine hydrothermal vents. Nature, 342:168-170. 
Campbell, A.C., Palmer, M.R., Klinkhammer, G.P., Bowers, T.S., Edmond, J.M., Lawrence, J.R., Casey, J.F., Thompson, G., Humphris, S., Rona, P.A., and Karson, J.A., 1988. Chemistry of hot springs on the Mid-Atlantic Ridge. Nature, 335:514-519.

Fletcher, J.M., Bartley, J.M., Martin, M.W., Glazner, A.F., and Walker, J.D., 1995. Large-magnitude continental extension: an example from the central Mojave metamorphic core complex. Geol. Soc. Am. Bull., 107:14681483.

Gregory, R.T., and Taylor, H.P., Jr., 1981. An oxygen isotope profile in a section of Cretaceous oceanic crust, Samail ophiolite, Oman: evidence for $\delta^{18} \mathrm{O}$-buffering of the oceans by deep $(>5 \mathrm{~km})$ seawater-hydrothermal circulation at mid-ocean ridges. J. Geophys. Res., 86:2737-2755.

Harper, G.D., Bowman, J.R., and Kuhns, R.J., 1988. A field, chemical, and stable isotope study of subseafloor metamorphism of the Josephine Ophiolite, California-Oregon. J. Geophys. Res., 93:4625-4656.

Karson, J.A., 1990. Seafloor spreading on the Mid-Atlantic Ridge: implications for the structure of ophiolites and oceanic lithosphere produced in slow-spreading environments. In Malpas, J., Moores, E.M., Panayiotou, A., and Xenophontos, C. (Eds.), Ophiolites: Oceanic Crustal Analogues: Proc. Symp. "Troodos 1987": Nicosia, Cyprus (Minist. Agric. Nat. Resour.), 547-555.

Laverne, C., Vanko, D.A., Tartarotti, P., and Alt, J.C., 1995. Chemistry and geothermometry of secondary minerals from the deep sheeted dike complex, Hole 504B. In Erzinger, J., Becker, K., Dick, H.J.B., and Stokking, L.B. (Eds.), Proc. ODP, Sci. Results, 137/140: College Station, TX (Ocean Drilling Program), 167-190.

Lécuyer, C., Brouxel, M., and Albaréde, F., 1990. Elemental fluxes during hydrothermal alteration of Trinity Ophiolite (California, U.S.A.) by seawater. Chem. Geol., 89:87-115.

Lister, C.R.B., 1977. Qualitative models of spreading-center processes including hydrothermal penetration. Tectonophysics, 37:203-218.

, 1980. Heat flow and hydrothermal circulation. Annu. Rev. Earth Planet. Sci., 8:95-117.

Mével, C., 1987. Evolution of oceanic gabbros from DSDP Leg 82: influence of the fluid phase on metamorphic crystallizations. Earth Planet. Sci. Lett., 83:67-79.

1988. Metamorphism of oceanic layer 3, Gorringe Bank, eastern Atlantic. Contrib. Mineral. Petrol., 100:496-509.
Mével, C., and Cannat, M., 1991. Lithospheric stretching and hydrothermal processes in oceanic gabbros from slow-spreading ridges. In Peters, T., Nicolas, A., and Coleman, R.J. (Eds.), Ophiolite Genesis and Evolution of the Oceanic Lithosphere. Petrol. Struct. Geol., 5:293-312.

Mottl, M.J., 1983. Metabasalts, axial hot springs, and the structure of hydrothermal systems at mid-ocean ridges. Geol. Soc. Am. Bull., 94:161-180.

Nehlig, P., Juteau, T., Bendel, V., and Cotten, J., 1994. The root zone of oceanic hydrothermal systems: constraints from the Samail ophiolite (Oman). J. Geophys. Res., 99:4703-4713.

Robie, R.A., and Waldbaum, D.R., 1968. Thermodynamic Properties of Minerals and Related Substances at $298.15^{\circ} \mathrm{K}\left(25.0^{\circ} \mathrm{C}\right)$ and One Atmosphere (1.013 Bars) Pressure and at Higher Temperatures. U.S. Geol. Surv. Bull., 125.

Shipboard Scientific Party, 1995. Site 922. In Cannat, M., Karson, J.A., Miller, D.J., et al., Proc. ODP, Init. Repts., 153: College Station, TX (Ocean Drilling Program), 179-215.

Spear, F.S., 1980. NaSiCaAl exchange equilibrium between plagioclase and amphibole: an empirical model. Contrib. Mineral. Petrol., 72:33-41.

, 1993. Metamorphic Phase Equilibria and Pressure-TemperatureTime Paths: Washington (Mineral. Soc. Am.), Monogr. 1.

Spear, F.S., and Peacock, S.M., 1989. Metamorphic Pressure-TemperatureTime Paths. Am. Geophys. Union Short Course in Geology, 7.

Stakes, D.S., and O'Neil, J.R., 1982. Mineralogy and stable isotope geochemistry of hydrothermally altered oceanic rocks. Earth Planet. Sci. Lett., 57:285-304.

Thompson, J.B., 1982. Reaction space: an algebraic and geometric approach In Ferry, J.M. (Ed.), Characterization of Metamorphism through Mineralogical Phase Equilibria. Mineral. Soc. Am., Rev. Mineral., 10:33-51.

Von Damm, K.L., 1990. Seafloor hydrothermal activity: black smoker chemistry and chimneys. Annu. Rev. Earth Planet. Sci., 18:173-204.

Date of initial receipt: 15 August 1995

Date of acceptance: 6 February 1996

Ms 153SR-036 